\title{
EFFECT OF SALT STRESS ON IONIC ACCUMULATION AND BIOCHEMICAL BEHAVIOROF CHICKPEA (CICER ARIETINUM L.)
}

\author{
Koulali $\mathbf{F}^{1^{*}}$, Sehari $\mathbf{M}^{1}$, Kouadria $\mathbf{M}^{1}$, Hassani $\mathbf{A}^{1}$ \\ ${ }^{1 *}$ University Ibn Khaldoun of Tiaret, Algeria, Faculty of Natural and Life Sciences, \\ Laboratory of Agrobiotechnology and Nutrition in dry areas, Algeria; \\ *Corresponding Author Fatiha Koulali, e-mail: fatihacom2007@yahoo.fr;
}

Received August 2021; Accepted September 2021; Published October 2021;

DOI: https://doi.org/10.31407/ijees11.437

\begin{abstract}
Salt stress affects plants' metabolism negatively. It causes a reduction in the osmotic potential and ionic toxicity through significant accumulation of $\mathrm{Na}^{+}$in tissues. Also, it leads to a nutritional imbalance. In response to these effects, plants synthesize organic compounds called osmolytes with osmoprotective action such as proline and soluble sugars. They are important in osmotic adjustment to limit water loss and to maintain cell turgor, which motivates the development of metabolic processes in plants. Accordingly, one of the most sensitive plants to salinity is chickpeas, widely consumed by humans. The aim of this work is to identify some biochemical and mineral criteria involved in the tolerance of six chickpea genotypes subjected to high concentrations of $\mathrm{NaCl}(0,50,75,100 \mathrm{mM})$. The obtained results showed the salinity had a depressive effect on the rate of proteins and on soluble sugars (2.50 mg.g ${ }^{-1}$ Fresh Mater FM) except for the Collection 28 genotype (4.707 mg.g $\left.{ }^{-1} \mathrm{FM}\right)$, Ghab4 (3.912 mg.g $\left.\mathrm{g}^{-1} \mathrm{FM}\right)$, and Belkhadem (3.949 mg. $\mathrm{g}^{-1} \mathrm{FM}$ ) which recorded a remarkable increase during severe stress. However, studied genotypes showed a significant accumulation of proline in leaves, around $125 \mathrm{mg} \cdot \mathrm{g}^{-1} \mathrm{FM}$ observed at $100 \mathrm{mM} \mathrm{NaCl}$ and an average of $55 \mathrm{mg} \cdot \mathrm{g}^{-1} \mathrm{FM}$ in the control. On the other hand, for the mineral balance, the genotypes were the "includer" type because they show a significant accumulation of $\mathrm{Na}^{+}$in leaves $\left(18 \mathrm{mg} \cdot 100 \mathrm{~g}^{-1}\right.$ Dry Matter DM on average at $100 \mathrm{mM} \mathrm{NaCl}$ compared to the control, which displays an average of $7 \mathrm{mg} \cdot 100 \mathrm{~g}^{-1} \mathrm{DM}$ ). Whereas the $\mathrm{K}^{+}$ decreases $\left(50 \mathrm{mg} .100 \mathrm{~g}^{-1} \mathrm{DM}\right)$ but with a higher rate than the $\mathrm{Na}^{+}$regardless the applied dose of $\mathrm{NaCl}$.
\end{abstract}

Keywords: Osmotic stress, soluble sugars, proline, proteins, chickpeas, minerals 